\title{
Sosioøkonomiske og demografiske faktorer sett i forhold til selvmordsrisiko
}

\author{
Ved Ping Qin
}

Siden Durkheims arbeid om selvmord i 1897 har forholdet mellom sosioøkonomiske faktorer og selvmord vært omfattet av stor forskningsinteresse. Forskning har vist at dette forholdet sannsynligvis er multifaktorielt og involverer mange dimensjoner ved livet. Med basis i forskning på store befolkningsregistre gir denne artikkelen en oversikt.

Etter at Émile Durkheim på 1800-tallet påpåpekte sammenhengen mellom sosiale relasjoner og selvmord (Durkheim, 1897/ 1966), har sosioøkonomiske faktorersinnvirkning på helse og velvære påkalt seg akademisk interesse. En omfatten de litteratur har helt konsekvent påvist et omvendt forhold mellom samlet dødelighet og sosioøkonomisk status, uansett hvilken sosioøkonomisk faktor som er benyttet, hvilket mål på helsemessige utfall som er brukt og hvilke spesifikke dødsårsaker som er studert (Fuhrer et al., 2002; H ouweling et al., 2001). Selvmord som en vesentlig årsak til dødsfall blant unge mennesker ses ofte i sammenheng med en rekke individuelle sosiale og økonomiske faktorer, som inntekt, tilknytning til arbeidsmarkedet, etnisitet, ekteskapelig status, barnefødsler og bosted (Blakely et al., 2003; Johansson et al., 1997; Lewis \& Sloggett, 1998; Platt \& H awton, 2000). Det er grunn til å tro at sammenhengen mellom sosioøkonomiske faktorer og selvmord kan tilskrives mange forhold. I noen få studier har man også trukket inn variabler som gjenspeiler ulike dimensjoner av sosial og økonomisk status for å anslå deres relative betydning. I midlertid inntar menn og kvinner ulike roller i familien og samfunnet, og sosioøkonomiske ulikheter er ofte kjønnsspesifikke. Følgelig kan en ufordelaktig sosial og økonomisk status påvirke menns og kvinners beslutning om å ta sitt eget liv på forskjellig måte. Dette har man sett nærmere på i en rekke epidemiologiske studier ved å benytte både individdata og befolkningsdata, men resultatene er ikke konsistente (Blakely et al., 2003; Johansson et al., 1997; Lewis et al., 1998).

Danmark har et velfungeren de system for registrering av befolkningsdata som omfatter personregistreringer av longitudinelle data på en rekke felt. M uligheten for å hente ut data fra forskjellige danske registre har gjort det mulig for oss å gjennomføre større befolkningsstudier av selvmord og dessuten satt oss i stand til å evaluere den relative betydningen av en rekke faktorer som ses i sammenheng med selvmord. I denne artikkelen gis en oversikt over forholdet mellom selvmordsrisiko og sosioøkonomiske og demografiske faktorer samt de kjønnsforskjellene som eksisterer, hovedsakelig basert på funn fra omfattende studier som har benyttet data fra danske befolkningsregistre.

\section{Ekteskap og foreldreskap}

Det antas at ekteskap virker forebyggende på selvmord ved at det sørger for et emosjonelt tilfluktssted, økonomisk stabilitet og sosial integrering. Dette er i tråd med Durkheims påstander i hans banebrytende bok om selvmord (Durkheim, 1897/1966), nemlig at det ikke bare er det å være gift, men familielivet som forebygger selvmord, og at særlig det å være forelder er en avgjørende forebyggende faktor mot selvmord blant gifte par.

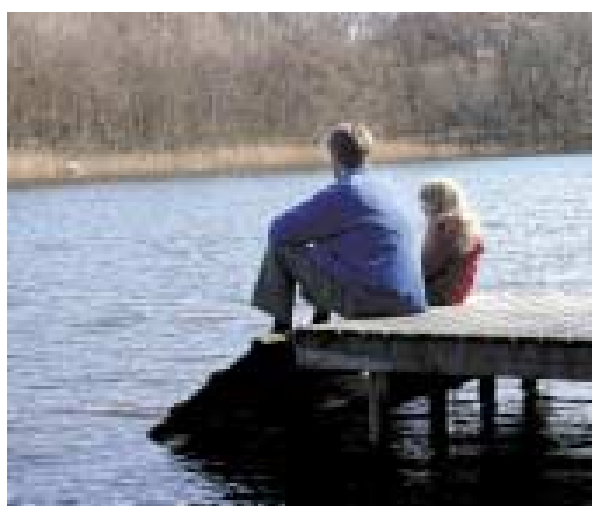

Ekteskapets forebyggende virkning for sel vmord er gjentatte ganger blitt dokumentert i mange studier som er omtalt i litteraturen (C antor \& Slater, 1995; H eikkinen et al., 1995). V år studie, som tar utgangspunkt i registerdata som omfatter hele Danmarks befolkning ( $Q$ in et al., 2003a), viser at sammenlignet med gifte personer var sel vmordsrisikoen signifikant høyere så vel blant single personer (1,9 ganger) som blant samboere (1,3 ganger), dette til tross for at samboerskap nærmest er sidestilt med offisielt godkjente ekteskapsforhold sett med de fleste danskers øyne. Denne studien ( $Q$ in et al., 2003a) tydet dessuten på at registrerte partnere (dvs. homofile par som innehar samme juridiske status som gifte par) var over 3,6 ganger mer utsatt for å ta sitt eget liv etter at man hadde justert for andre sosioøkonomiske faktorer samt psykiatrisk status. Den reduserte risikoen for selvmord som ses i sammenheng med det å være gift, kan skyldes den forebyggen de virkningen ekteskap gir (f.eks. ved at den ene ektefellen motiverer den andre til å holde seg i live eller yter vedkommende støtte når denne opplever tilbakeslag), ekteskapets selektive virkning (dvs. at personer med dårlig helse har redusert sannsynlighet for å bli gift) eller en kombinasjon av disse virkningene. $V$ åre funn om at selvmordsrisikoen økte trinnvis mellom kategoriene gifte, samboende, single og registrerte homofile forhold, synes å indikere at familiestruktur og familiesamhold har betydning for selvmord i det moderne samfunn, trolig fordi folk med en tradisjonell familieorientering har mindre sannsynlighet for å oppvise negativ helseatferd av noe slag og dermed er mindre utsatte for å ta sitt eget liv.

Samtidig finnes det evidensfor at foreldreskap kan ses i sammenheng med redusert risiko for suicidal atferd ( $C$ antor et al., 1995) . V år studie ( Q in \& M ortensen, 2003b) tydet videre på at den forebyggende virkningen foreldrerollen har, opptrer uavhengig av ekteskapelig, sosi oøkonomisk og psykiatrisk status hos både fedre og mødre, og at det å få et barn i ung alder i høyere grad så ut til å beskytte foreldre enn det å få flere barn i mer fremskreden alder. Disse resultatene tyder på at hensynet til barna i sterk grad påvirker en forelders beslutning om å avsl utte livet. Tilstedeværelsen av et lite barn ser i særlig grad ut til å øke foreldrenes oppfatning om at det er behov for dem og dermed hindre dem i å ta sitt eget liv.

Videre virker det som om ekteskap og forel dreskap har ulike innvirkninger på menn og kvinners selvmordsrisiko. $V$ åre studier (Q in et al., 2000; Q in et al., 2003b; Q in et al., 2003a) tyder på at det å være gift virker mer forebyggen de på selvmord for menn enn for kvinner, mens 


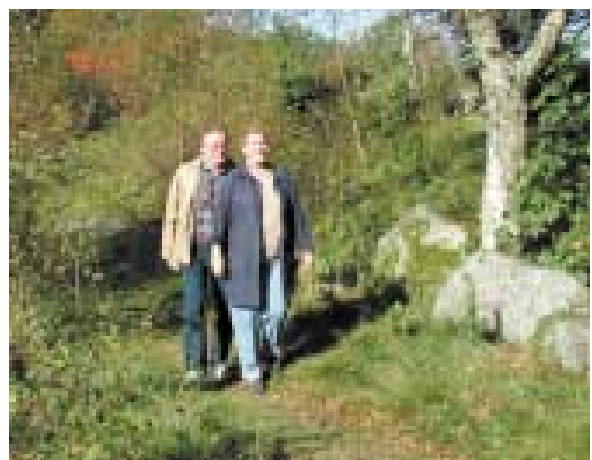

foreldrerollen virket mer forebyggende på selvmord for kvinner enn for menn. Samtidig viser vårt arbeid at den innvirkningen foreldreskap (f.eks. å ha barn og/eller ha et lite barn) hadde på risikoen for selvmord, ikke varierte med ekteskapelig status hos kvinner, mens den varierte signifikant med ekteskapelig status hos menn. Det å være forelder reduserte selvmordsrisikoen for menn som var gift eller samboende, mens det økte risikoen for menn som levde som single ( $Q$ in et al., 2003b). De tendensene som disse resultatene avtegner, støtter Durkheims hypotese (1897/1966) om at ekteskapets forebyggende virkning mot selvmordsrisiko blant kvinner, i høy grad kan føres tilbake til det å ha barn. R esultatene kan med andre ord implisere at det å være forelder til et lite barn, synes å forklare ekteskapets tilsynelaten de forebyggende virkning for kvinner snarere enn ekteskapelig status per se, mens ekteskap for menns vedkommende ser ut til å være en forebyggende faktor i kraft av seg selv. Dette kommer imidlertid ikke i konflikt med foreldrerollens forebyggen de innvirkning på selvmord blant menn. Den negative virkningen det å ha barn har på fedre som lever som single, kan langt på vei skyldes at det er færre fedre enn mødre som har forel dreansvar for barna når foreldrene er separerte eller skilte.

På den annen side viste vår forskning også at tap av et barn i høy grad øker risikoen for selvmord både for menn og kvinner, og at den relative risikoen faktisk økte når den ble justert for andre risikofaktorer ( $Q$ in et al., 2003b). Virkningen var særlig markert for foreldre som hadde opplevd å se et barn dø tidlig i barndommen, for så å avta noe når et barn hadde dødd på et senere alderstrinn. Disse funnene tyder på at tapet av et barn i høyere grad enn andre faktorer kan være medvirkende til foreldres ønske om å dø, og dette er særlig tilfellet når de mister et barn som sannsynligvis er sterkt knyttet til og avhengig av foreldrene.

\section{Tilknytning til arbeidsmarkedet og inntekt}

Risikoen for selvmord er generelt høy blant personer som opplever økonomiske stressfaktorer som det å være arbeidsløse, ha lav inntekt eller stå overfor økonomiske problemer (Johansson \& Sundquist, 1997; Lewis et al., 1998). Etter en systematisk gjennomgang av litteraturen fra 1984 og fremover konkluderte Platt og $\mathrm{H}$ awton (2000) med at arbeidsløshet i signifikant grad økte risikoen for selvmord på individuelt plan. Våre studier ( $M$ ortensen et al., 2000; Q in et al., 2003a) viste helt konsekvent signifikante høye risiki for selvmord i samband med arbeidsløshet, uføretrygding, lav inntektsstatus og lav formuesstatus når man bare justerer for alder og kjønn. I midlertid viste vår studie også at de økte risiki som ses i sammenheng med disse variablene, i betydelig grad avtok og faktisk ble reversert når de ble ytterligere justert for psykiatriske og andre faktorer, noe som tyder på at de sosioøkonomiske faktorenes innvirkning på selvmord synes å være overvurdert når det bidraget psykiatriske lidelser gir, ikke tas i betraktning.

I tillegg tydet våre studier på at de virkningene arbeidsmarkedsstatus og inntekt har på selvmordsrisiko, varierte signifikant med kjønn (Q in et al., 2000; Q in et al., 2003a). For eksempel økte selvmordsrisikoen med økende grad av arbeidsløshet hos menn, mens det ikke ble påvist noen tilsvarende trend for kvinner. Sammenliknet med personer som hadde en årsinntekt i den høyeste kvartilen, hadde menn i den laveste kvartilen økt risiko, mens kvinner med middels inntektsnivå hadde redusert selvmordsrisiko ( $Q$ in et al., 2003a). Disse funnene støtter Durkheims teori (Durkheim, 1897/1966) om at menn reagerer sterkere på dårlige økonomiske forhold enn kvinner. Selv om $ø$ øonomiske stressfaktorer er vanlige for begge kjønn, kan man fremsette en hypotese om at menns roller og forventninger i familien og samfunnet lettere kan føre til redusert selvaktelse dersom mennene ikke er i stand til å leve opp til de forventningene som stilles dem, og de kan dermed påvirke deres tilbøyel ighet til og gjøre dem mer utsatte for selvmord.

\section{Etnisitet}

Parallelt med den økningen i migrasjon over landegren sene man ser i dagens samfunn, har forskningen viet selvmord blant innvandrere økende oppmerksomhet. Det spekuleres ofte i om den relative sosiale og økonomiske marginaliseringen av minoritetsgrupper fra majoritetssamfunnet, samt svekkel sen av tidligere familienettverk og sosiale nettverk, kan bidra til forhøyet selvmordsrisiko blant innvandrere. $\mathrm{N}$ oen få studier har påvist at personer som var født i andre land, hadde en signifikant høyere forekomst av selvmordsforsøk og dødsfall forårsaket av selvmord, sammenliknet med den innfødte befolkningen i et gitt samfunn ( $N$ eeleman et al., 1997). I tråd med disse rapportene viste vår studie ( $Q$ in et al., 2003a) signifikant høyere selvmordsrisiko blant danske borgere som var født i utlandet, sammenlignet med borgere som var født i Danmark. En annen dansk studie som behandler dette temaet (Sundaram et al., 2006), gav et tilsvarende resultat, nemlig at selvmordsrisikoen generelt var høyere hos personer med utenlandsk bakgrunn sammenlignet med personer som var født i Danmark av danskfødt foreldre. Imidlertid varierte risikoen signifikant med kjønn og for grupper med ulik etnisk bakgrunn. Den økte risikoen for selvmord begrenset seg hovedsakelig til kvinner som var født i nordiske land (andre enn Danmark), Øst-Europa og A sia. Imidlertid ble det ikkekonstatert økt risiko for menn som var født i de nevnte regionene, og menn som var født i A sia, hadde tvert imot relativt lavere risiko for selvmord, sammenlignet med sine motparter av samme kjønn som var født i Danmark av danske foreldre. Samtidig viste denne studien (Sundaram et al., 2006) også at selvmordsrisikoen var signifikant høyere for personer som var født i fremmede land, men hadde dansk-fødte foreldre (hovedsakelig adoptivbarn), eller som var født i Danmark, men hadde minst én forelder som var født i utlandet (hovedsakelig andregenerasjons innvandrere).

Forklaringer på den generelt økte risikoen blant innvandrere kan blant annet være kulturelle forskjeller i holdninger 
til selvmordsatferd fra land til land, manglende sosial samhørighet og integrering samt svake sosiale relasjoner eller nettverk generelt. De signifikante kjønnsforskjellene kan på sin side forklares med at mannlige og kvinnelige innvandrere kommer fra et forskjellig spekter av land, samt med ulike målsetninger for innvandringen blant menn og kvinner. Danmark er et land med forholdsvis få innvandrere, og kvinnelige innvandrere kom i mange tilfeller fra vesteuropeiske og andre nordiske land med en generelt høy selvmordsfrekvens for kvinner, mens mannlige innvandrere - især menn uten dansk statsborgerskap - kom fra et bredere spektrum av land. Det faktum at en forholdsvis stor andel av mannlige innvandrere kom fra islamske land, der selvmordsfrekvensen tradisjonelt er lav, kan også ha bidratt til våre funn. En annen forklaring kan være at kvinner i mange tilfeller har innvandret til Danmark for å bli gjenforent med familien, ikke for å arbeide eller drive forretningsvirksomhet. Følgelig hadde de færre kontakter med andre mennesker, levde mer isolert fra samfunnet, var mindre selvstendige og var utsatt for flere stressfaktorer enn mannlige innvandrere. Konflikter som skyldes kulturelle verdier og forvirring med hensyn til egen identitet, kan også bidra til den økte risikoen for selvmord blant første- og andregenerasjons innvandrere foruten blant adoptivbarn.

\section{Bosted og urbanitet}

Selvmordsraten oppviser stor variasjon i mange henseender, blant dem bosted. Forskjellen mellom by og land med hensyn til selvmordsrater har vært tydelig helt fra begynnelsen, selv om det mønsteret forskjellene avslører, kan variere fra ett samfunn til et annet. Studier fra enkelte vestlige land som tar for seg både hele populasjoner og enkeltpersoner, har konsekvent vist at folk som bor i større

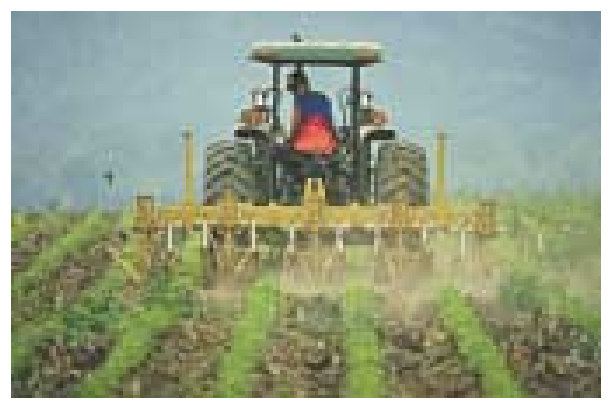

bysamfunn, har økt risiko for selvmord sammenlignet med sine motparter som bor i landlige områder ( $\mathrm{H}$ eikkinen et al., 1997; M icciolo et al., 1991). V åre studier ( $Q$ in et al., 2003a; Q in, 2005) viste videre at sel vmordsrisikoen i befolkningen generelt økte progressivt etter hvert som bostedets urbanitet økte. Den høyeste risikoen (1,58 ganger) rammet folk som bodde i hovedstaden.

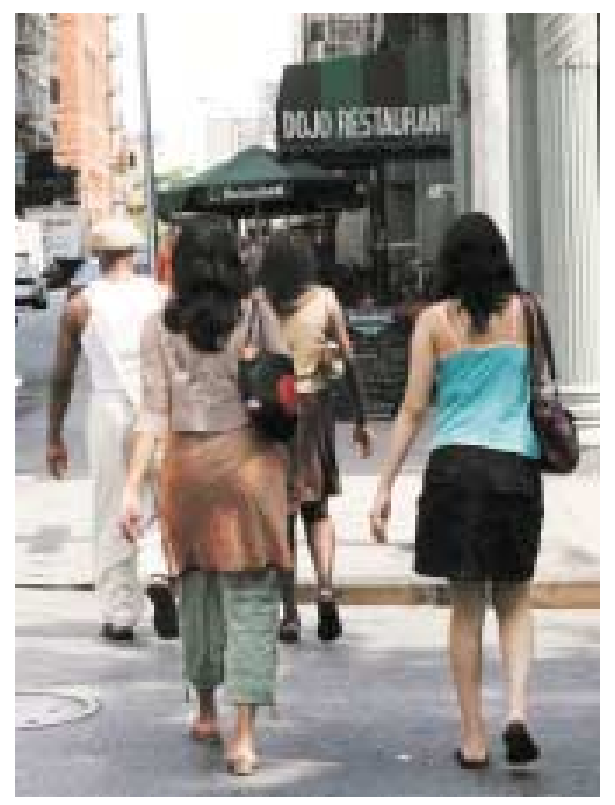

Samtidig er det påvist en motsatt ten dens i forskjeller i selvmordsfrekvens for by og land $i$ andre land som Kina (Phillips et al., 2002; Q in \& M ortensen, 2001), H ellas (Zacharakis et al., 1998) og USA (2006). Videre har studier fra for eksempel A ustralia (Taylor et al., 2005) og Storbritannia (Saunderson et al., 1998), faktisk også vist en ulik disparitet for by og land når det gjelder menn og kvinner, og tendensen var at kvinners selvmordsrater var signifikant høy i tettbygde strøk, mens menns selvmordsrater var høyest i de mest landlige områdene.

Imidlertid ser det ut til at de observerte forskjellene i selvmordsrate mellom by og land generelt synes å bli sterkt modifisert av faktorer som sosioøkonomisk status, tilgang til hel setjenester og sosial støtte ved at disse faktorene fordeler seg ulikt mellom urbane og landlige samfunn. $V$ år studie, der vi benyttet danske longitudinelle data fra befolkningsregistre ( $Q$ in, 2005), viste at på individplan ble den forhøyede risikoen for selvmord som knyttet seg til det å leve i urbaniserte områder, i høy grad eliminert når den ble justert for personlig ekteskapelig status, inntekt og etnisitet; den ble til og med reversert năr den ble ytterligere justert for psykiatrisk status. Lagdelte analyser etter alder har vist at når man tar virkningene av sosio$ø$ konomiske og psykiatriske faktorer med i betraktning, øker det å leve i urbaniserte områder selvmordsrisikoen for kvinner i alle aldersgrupper. Derimot reduserer det risikoen for selvmord blant menn i nesten alle aldersgrupper, og den forebyggende virkningen synes å være mer uttalt for unge menn. Tilsvarende, men på samfunn splan, viste en studie fra A ustralia (Taylor et al., 2005) at den høyere selvmordsraten for menn i landlige områder i A ustralia, sammenlignet med urbane områder, ble ikke-signifikant etter å ha blitt justert for innvandringsstatus og omrădets sosioøkonomiske status. Den ble ytterligere redusert med tilleggsjustering for utbredelse av psykiske lidelser og utnytting av tilbud om psykiatriske helsetjen ester. Disse resultatene tyder på at forskjellene i selvmordsfrekvens mellom by og land langt på vei kan forklares ved hjelp av de iboende forskjellene mellom by og land med hensyn til faktorer som ekteskapelig status, etnisk sammensetning, inntekt og især psykiatrisk status og relevante tjenester. Det tyder med andre ord på at disse faktorene, ikke bostedet per se, antakelig er mer grunnleggende risikofaktorer for selvmord.

Det økende tempoet i urbanisering eller sosial overgang har i den senere tid gjort at forskningen har viet sin oppmerksomhet til korresponderende endringer $i$ selvmordsrisiko knyttet til bosted. V år studie, der vi benyttet individdata for å se på utviklingen av selvmordsrisiko kontra urbanitet fra 1981 til 1997 (Q in, 2005), tydet på at selvmordsrisiko knyttet til urbanitet i løpet av den tiden studien pågikk, var temmelig konstant for kvinner. H os menn endret den seg imidlertid signifikant med en avtakende trend for forskjellene mellom by og land. Etter å ha blitt justert for personlig sosioøkonomisk og psykiatrisk status ble den reduserte risikoen for selvmord hos menn som bodde i urbaniserte områder, mer fremtreden de mot slutten av perioden, særlig når det gjaldt effekten som knyttet seg til det å bo i hovedstaden. Sammenlignbare resul- 
tater er også registrert i rapporter der man har benyttet befolkningsdata fra N orge (M ehlum et al., 1999), A ustralia (Dudley et al., 1992), U SA (Singh \& Siahpush, 2002) og Storbritannia (M iddleton et al., 2003), og som har påvist en økning i rurale selvmordsrater, sammenlignet med ratene i urbaniserte samfunn de siste tiårene.

D et er grunn til å tro at de observerte forskjellene i selvmordsrater mellom by og land skyldes en kombinasjon av karakteristika ved individer bosatt på spesifikke steder, muligh etsstrukturer og karakteristikker i det lokale fysiske og sosiale miljøet, samt samfunnenes sosiokulturelle og historiske forhold. Den sekulære trenden for forskjeller mellom by og land med hensyn til selvmord er derfor en følge av endringer i disse faktorene som har inntrådt etter hvert som urbaniseringen i det moderne samfunn har økt.

Kort oppsummert er sammenhengen mellom sosioøkonomiske og demografiske forhold og selvmord trolig multifaktoriell, der variabler fra ulike dimensjoner er involvert. På individplan impliserer sosial klasse ulik eksponering for fysiske, psykologiske, miljømessige og yrkesmessige faktorer, samt forskjeller i tilgang til helsetjenester, i livskvalitet og livsstil. A Ile disse faktorene har potensiell innvirkning på reaksjoner i retning av selvmord. En bedret forståelse av disse faktorene og deres kjønns- og/eller aldersforskjeller, samt de mekanismene som ligger til grunn for disse variasjonene, er avgjørende for å finne frem til selvmordsforebyggende strategier.

(A rtikkelen er oversatt av Dag Biseth.)

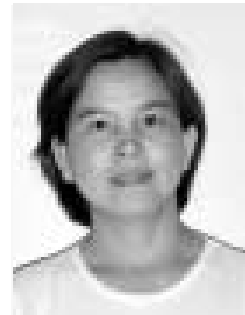

D r. Ping $\mathbf{Q}$ in er utdannet lege og arbeider som forsker og lektor i psykiatrisk epidemiologi ved det nasjonale senter for registerbasert forskning ved U niversitetet i Å rhus. I løpet av de siste 10 år har hun utført omfattende epidemiologiske studier om selvmord og psykisk lidelse på basis av data fra ulike longitudinelle danske befolkningsregistre og har publisert en rekke arbeider $\mathrm{i}$ toneangivende tidsskrifter. Dr Q in deltar aktivt i det selvmordsforebyggende arbeidet i Danmark og er styremedlem i den danske foreningen for selvmordsforskning og -forebygging.

\section{Referanser}

C enters for Disease Control. (2006). Suicide: Fact sheet (www.cdc.gov/ncipc/factsheets/suifacts.htm).

Blakely, T. A ., Collings, S. C., \& A tkinson, J. (2003). U nemployment and suicide. Evidence for a causal association? J.Epidemiol.C ommunity $H$ ealth, 57, 594-600.

Cantor, C. H. \& Slater, P. J. (1995). M arital breakdown, parenthood and suicide. Journal of Family Studies, 1, 91-102.

Dudley, M ., Waters, B., Kelk, N ., \& H oward, J. (1992). Youth suicide in $N$ ew South Wales: urban-rural trends. M ed.J. A ust., \%20;156, 83-88.

Durkheim, E. (1966). Suicide (trans. J.A .Spaulding $\&$ G.Simpson). N ew York: The Free Press. (utkom første gang i 1897)

Fuhrer, R., Shipley, M. J., C hastang, J. F., Schmaus, A ., N iedhammer, I., Stansfeld, S. A . et al. (2002). Socioeconomic position, health, and possible explanations: a tale of two cohorts. A m.J.Public $\mathrm{H}$ ealth., 92, 1290-1294.

H eikkinen, M ., A ro, H ., \& Lonnqvist, J. (1994). Recent life events, social support and suicide. A cta Psychiatr Scand Suppl., 377, 65-72.

H eikkinen, M . E., Isometsa, E. T., M arttunen, M J., A ro, H. M ., \& Lonnqvist, J. K. (1995). Social factors in suicide. BrJ Psychiatry, 167, 747-753.

H ouweling, T. A ., Kunst, A . E., \& M ackenbach, J. P. (2001). World H ealth R eport 2000: inequality index and socioeconomic inequalities in mortality. Lancet., 357, 1671-1672.

Johansson, L. M., Sundquist, J., Johansson, S. E., \& Bergman, B. (1997). Ethnicity, social factors, illness and suicide: a follow-up study of a random sample of the Swedish population. A cta Psychiatr Scand, 95, 125-131.

Johansson, L. M ., Sundquist, J., Johansson, S. E., Q vist, J., \& Bergman, B. (1997). T he influence of ethnicity and social and demographic factors on Swedish suicide rates. A four year follow-up study. Soc Psychiatry Psychiatr Epidemiol., 32, 165-170.

Johansson, S. E. \& Sundquist, J. (1997). U nemployment is an important risk factor for suicide in contemporary Sweden: an 11-year follow-up study of a cross-sectional sample of 37,789 people. Public H ealth, 111, 41-45.

Lewis, G. \& Sloggett, A . (1998). Suicide, deprivation, and unemployment: record linkage study. BMJ, 317, 1283-1286.

M ehlum L, H ytten K, \& G jertsen F (1999). Epidemiological trends of youth suicide in N orway. A rchives of Suicide Research, 193-205.

Micciolo, R., W illiams, P., Zimmermann-Tansella, C., \& Tansella, M . (1991). G eographical and urban-rural variation in the seasonality of suicide: some further evidence. J.A ffect.D isord., 21, 39-43.
Middleton, N ., G unnell, D., Frankel, S., W hitley, E., \& D orling, D. (2003). U rban-rural differences in suicide trends in young adults: England and Wales, 1981-1998. Soc.Sci.M ed., 57, 1183-1194.

M ortensen, P. B., A gerbo, E., Erikson, T., Q in, P., $\&$ W estergaard-N iel sen, N . (2000). Psychiatric illness and risk factors for suicide in D enmark. Lancet, 355, 9-12.

N eeleman, J., H alpern, D., Leon, D., \& Lewis, G. (1997). Tolerance of suicide, religion and suicide rates: an ecological and individual study in $\mathbf{1 9}$ Western countries. Psychol M ed, 27, 1165-1171.

Phillips, M . R., Li, X., \& Zhang, Y. (2002). Suicide rates in C hina, 1995-99. Lancet., 359, 835-840.

Platt, S. \& H awton, K. (2000). Suicide B ehaviour and the labour market. In Keith $\mathrm{H}$ awton \& Kees van $H$ eeringen (Eds.), The international handbook of suicide and attempted suicide (pp. 309-384). Chichester: Wiley.

Q in, P. (2005). Suicide risk in relation to level of urbanicity--a population-based linkage study. Int.J.Epidemiol., 34, 846-852.

Q in, P., A gerbo, E., \& M ortensen, P. B. (2003a). Suicide risk in relation to socioeconomic, demographic, psychiatric, and familial factors: a national register-based study of all suicides in D enmark, 1981-1997. A m.J Psychiatry, 160, 765772.

Q in, P. \& M ortensen, P. B. (2001). Specific characteristics of suicide in C hina. A cta Psychiatr Scand, 103, 117-121.

Q in, P. \& M ortensen, P. B. (2003b). T he impact of parental status on the risk of completed suicide. A rch.Gen.Psychiatry, 60, 797-802.

Q in, P., M ortensen, P. B., A gerbo, E., W estergard$\mathrm{N}$ ielsen, N ., \& Eriksson, T. (2000). G ender differences in risk factors for suicide in $D$ enmark. Br.J.Psychiatry, 177, 546-550.

Saunderson, T., H aynes, R., \& Langford, I. H. (1998). U rban-rural variations in suicides and undetermined deaths in England and W ales. J.Public H ealth M ed., 20, 261-267.

Singh, G. K. \& Siahpush, M. (2002). Increasing rural-urban gradients in U S suicide mortality, 1970-1997. A m.. .Public H eal th, 92, 1161-1167.

Sundaram, V., Q in, P., \& Zollner, L. (2006). Suicide risk among persons with foreign background in D enmark. Suicide Life T hreat.Behav., 36, 481489.

Taylor, R ., Page, A ., M orrell, S., H arrison, J., \& Carter, G. (2005). Social and psychiatric influences on urban-rural differentials in A ustralian suicide. Suicide Life Threat.Behav., 35, 277-290.

Zacharakis, C. A ., M adianos, M. G., Papadimitriou, G. N ., \& Stefanis, C. N . (1998). Suicide in G reece 1980-1995: patterns and social factors. Soc.Psychiatry Psychiatr.Epi demiol., 33, 471-476. 